\title{
Preterm delivery in infertile women after reproductive surgery: should we encourage spontaneous conception?
}

\author{
Tanja Premru-Srsen ${ }^{1}$, Eda Bokal Vrtačnik ${ }^{1}$, Tina Bizjak ${ }^{2}$, Ivan Verdenik ${ }^{3}$, Sara Korošec ${ }^{1}$, \\ and Helena Ban Frangez ${ }^{1}$ \\ ${ }^{1}$ UMC Ljubljana \\ ${ }^{2}$ General Hospital Slovenj Gradec \\ ${ }^{3}$ University Medical Centre Ljubljana
}

June 3, 2020

\begin{abstract}
Objective: To evaluate an association between the mode of conception and preterm delivery in women after reproductive surgery, and to explore an effect of reproductive surgery on preterm delivery. Design: Prospective cohort study and historical case-control study. Setting: Division of Obstetrics and Gynecology, Ljubljana, Slovenia. Population or sample: A cohort of 761 infertile women after reproductive surgery. Methods: In infertile women, we evaluated the association between the mode of conception and preterm delivery using logistic regression adjusted for relevant co-variables. In a case-control study, we evaluated the effect of reproductive surgery on preterm delivery using propensity score method. We calculated the adjusted odds ratios with a $95 \%$ confidence interval with a two-way test. Main Outcome Measure: Preterm delivery. Results: Among 761 infertile women, $428(56.2 \%)$ conceived spontaneously, and $333(43.8 \%)$ conceived after IVF/ICSI. The incidence of twin pregnancies was significantly lower after spontaneous conception $(2.6 \%$ vs. $14.1 \% ; \mathrm{p}<0.000)$. Adjusted logistic regression analysis in singleton pregnancies disclosed no significant association between the mode of conception and preterm delivery. Compared with fertile women, the incidences of preterm deliveries $<37$, and $<32$ gestational weeks were higher in infertile women $(11.2 \%$ vs. $14.2 \%$, and $1.7 \%$ vs. $2.6 \%$, respectively). However, the differences did not reach a statistical significance $(\mathrm{p}=0.076$ and $\mathrm{p}=0.218$, respectively). Conclusion: In selected infertile women after reproductive surgery, a high rate of spontaneous conception, a low rate of multiple pregnancies, and no treatment-related adverse effect on preterm delivery should be the reasons to encourage spontaneous conception after reproductive surgery.
\end{abstract}

Preterm delivery in infertile women after reproductive surgery: should we encourage spontaneous conception?

Tanja Premru-Srsen ${ }^{\mathrm{a}, \mathrm{b}}$, Eda Bokal Vrtačnik ${ }^{\mathrm{b}, \mathrm{c}}$, Tina Bizjak ${ }^{\mathrm{d}}$, Ivan Verdenik ${ }^{\mathrm{e}}$, Sara Korošec ${ }^{\mathrm{b}, \mathrm{c}}$, Helena Ban Frangež ${ }^{b, c}$

${ }^{a}$ Department of Perinatology, Division of Obstetrics and Gynecology, University Medical Centre Ljubljana, Šlajmarjeva 3, 1000 Ljubljana, Slovenia

tanja.premru@kclj.si (Tanja Premru-Srsen)

${ }^{\mathrm{b}}$ Medical Faculty, University of Ljubljana, Vrazov trg 2, 1000 Ljubljana, Slovenia

${ }^{\mathrm{c}}$ Department of Human Reproduction, Division of Obstetrics and Gynecology, University Medical Centre Ljubljana, Šlajmarjeva 3, 1000 Ljubljana, Slovenia

sara.korosec@kclj.si,eda.bokal@guest.arnes.si, helena.ban.frangez@gmail.com 
${ }^{\mathrm{d}}$ Departemnt of Obstetrics and Gynecology, General Hospital Slovenj Gradec, Gosposvetska cesta 1, 2380 Slovenj Gradec, Slovenia

tinejsn@gmail.com (Tina Bizjak)

${ }^{\text {e}}$ Research Unit, Division of Obstetrics and Gynecology, University Medical Centre

Ljubljana, Šlajmarjeva 3, 1000 Ljubljana, Slovenia

ivan.verdenik@guest.arnes.si

\section{Corresponding author}

Helena Ban Frangež, M.D., Ph.D.

Department of Human Reproduction, Division of Obstetrics and Gynecology, University Medical Centre Ljubljana

Šlajmarjeva 3, 1000 Ljubljana, Slovenia

GSM: 38641336441

helena.ban.frangez@gmail.com

Running title : Preterm delivery after reproductive surgery

\section{Abstract}

Objective: To evaluate an association between the mode of conception and preterm delivery in women after reproductive surgery, and to explore an effect of reproductive surgery on preterm delivery.

Design : Prospective cohort study and historical case-control study.

Setting : Division of Obstetrics and Gynecology, Ljubljana, Slovenia.

Population or sample : A cohort of 761 infertile women after reproductive surgery.

Methods : In infertile women, we evaluated the association between the mode of conception and preterm delivery using logistic regression adjusted for relevant co-variables. In a case-control study we evaluated the effect of reproductive surgery on preterm delivery using propensity score method. We calculated the adjusted odds ratios with a $95 \%$ confidence interval with a two-way test.

Main Outcome Measure : Preterm delivery.

Results : Among 761 infertile women, 428 (56.2\%) conceived spontaneously, and 333 (43.8\%) conceived after IVF/ICSI. The incidence of twin pregnancies was significantly lower after spontaneous conception $(2.6 \%$ vs. $14.1 \% ; p<0.000)$. Adjusted logistic regression analysis in singleton pregnancies disclosed no significant association between the mode of conception and preterm delivery. Compared with fertile women, the incidences of preterm deliveries $<37$, and $<32$ gestational weeks were higher in infertile women $(11.2 \%$ vs. $14.2 \%$, and $1.7 \%$ vs. $2.6 \%$, respectively). However, the differences did not reach a statistical significance ( $p=0.076$ and $p=0.218$, respectively).

Conclusion: In selected infertile women after reproductive surgery, a high rate of spontaneous conception, a low rate of multiple pregnancies, and no treatment-related adverse effect on preterm delivery should be the reasons to encourage spontaneous conception after reproductive surgery.

Funding: The authors received no funding.

Keywords : reproductive surgery, preterm delivery, spontaneous conception, IVF/ICSI, infertile women

Tweetable abstract

In selected infertile women, spontaneous conception after reproductive surgery should be encouraged. 


\section{Introduction}

Preterm birth is one of the leading causes of neonatal morbidity, mortality, and severe long-term disability ${ }^{1}$. With the advance in infertility treatment, conception after in vitro fertilization (IVF) procedures has been recognized as a substantial increase in preterm delivery risk ${ }^{2}$. The increase in preterm delivery risk after IVF is found mainly due to the higher rate of multiple pregnancies, but also due to advanced maternal age, nulliparity, and co-morbidity ${ }^{2-6}$. However, some data demonstrate that adverse outcomes, preterm delivery included, occur in infertile women regardless of the mode of conception, IVF, or spontaneous, suggesting that infertility may be the underlying cause ${ }^{7}$.

While the body of studies exists on pregnancy rate and outcome in infertile women after IVF conception, there are scarce studies on pregnancy outcome of spontaneous conception after reproductive surgery ${ }^{8}$. The main reason exists in the opinion that reproductive surgery should only be performed as an initial part of infertility evaluation to increase implantation and pregnancy rates after IVF ${ }^{9}$. However, evidence shows that careful selection of patients for reproductive surgery enables couples to conceive spontaneously and yields high cumulative pregnancy rates and good outcomes ${ }^{8-10}$.

In the absence of obvious indication for IVF/ISCI procedure (like a male factor of infertility, bilateral tubal factor, or need for preimplantation genetic diagnostic), the usual approach to infertility treatment at our institution is, firstly, to restore fertility with reproductive surgery. Thus, every woman without any clear indication for IVF/ICSI undergo diagnostic or operative laparoscopy and, in the case of pathology found on transvaginal ultrasound, also a hysteroscopy. The usual overall pregnancy rate after reproductive surgery has been around $50 \%^{10}$. Women, who do not conceive spontaneously after reproductive surgery are advised to undergo IVF procedure.

Since the IVF/ICSI procedure has been supposed to be the known factor for preterm delivery ${ }^{4}$, we aimed to explore an association between the mode of conception, spontaneous or IVF/ICSI, and preterm delivery in a cohort of infertile women after reproductive surgery. We hypothesized that in infertile women after reproductive surgery, the mode of conception is not associated with preterm delivery risk. Also, the opinion is that any infertility treatment is associated with a higher risk of preterm delivery ${ }^{6}$. Thus, we aimed to explore the effect of reproductive surgery on preterm delivery as a treatment-related adverse outcome. We hypothesized that preterm delivery in infertile women is not a reproductive surgery treatment-related adverse outcome.

\section{Material and Methods}

\section{Study population}

Firstly, we conducted a prospective observational study of a cohort of 761 infertile women who underwent reproductive surgery and delivered at the Division of Obstetrics and Gynecology, University Medical Centre Ljubljana, Slovenia, from 1st July 2012 to 31st December 2015. Further on, a historical case-control study for evaluating preterm delivery as a reproductive surgery treatment-related side effect, a control group was selected among fertile women who delivered in Slovenia in the same period. In Slovenia, $99.9 \%$ of deliveries are in-hospital.

There was no patient and public involvement in the study.

\section{Data collection}

The anonymized data on women's demographic and clinical data, an indication and type of surgical treatment, pregnancy and delivery were obtained by linking three computerized databases: Computerized database of reproductive surgery at the Department of Human Reproduction, National Register of Assisted Reproduction Technology (NRART) and National Perinatal Information System (NPIS). The data included in databases are collected during the hospital stay by attending doctors, nurses, and midwives. The Computerized database of reproductive surgery was described in detail elsewhere (10). The NRART was introduced in 1983 at the Ministry of Health of Republic of Slovenia, and from 1999 the data are also sent to the IVF 
Monitoring (EIM) Consortium of the European Society of Human Reproduction and Embryology regularly. The data from NPIS, which also serves as a birth registry, are sent to the Slovenian National Institute of Public Health yearly where they go through statistical quality checks, are edited, and form the basis for the official perinatal Statistics of Slovenia. The data from NPIS are also sent to the Vermont Oxford Network and Euro-Peristat.

Dependent variables

Dependent variables were a preterm delivery $<37$, and $<32$ gestational weeks. Gestational age was derived from the day of ovarian punction or embryo transfer for IVF/ICSI pregnancies, and the measurement of the fetal crown-rump length in the first trimester for spontaneous pregnancies ${ }^{11}$.

\section{Independent variables}

The main independent variables were the mode of conception (spontaneous / IVF/ICSI) in the observational study, and infertility with reproductive surgery in the case-control study (yes / no).

Independent co-variables were maternal age (continuous), maternal age at delivery $>35$ years, pre-pregnancy body mass index (BMI) (continuous), BMI [?] $30 \mathrm{~kg} / \mathrm{m} 2$ (yes / no), BMI $<18.5 \mathrm{~kg} / \mathrm{m} 2$ (yes / no), gestational weight gain (GWG) z-score (continuous), GWG z-score $>-2$ (yes / no), GWG z-score $>2$ (yes / no), prepregnancy hypertension (yes / no), pre-pregnancy diabetes (yes / no), previous conization (yes / no), uterine anomalies (yes / no), chronic kidney disease (yes / no), other chronic diseases (heart, thyroid and/or mental disease) (yes / no), previous preterm delivery (yes / no), previous miscarriage (yes / no), smoking (yes / no), preeclampsia/eclampsia (yes / no), gestational diabetes (yes / no), small-for-gestational age neonate (birthweight $<$ 10th percentile) (yes / no), nulliparous (yes / no).

BMI was defined as the woman's body mass divided by the square of body stature $(\mathrm{kg} / \mathrm{m} 2)$. The pregravid BMI was categorized according to the Institute of Medicine criteria as underweight $(<18.5 \mathrm{~kg} / \mathrm{m} 2)$, normal weight (18.5-24.9 kg/m2), and overweight (15.0-29.9 $9 \mathrm{~kg} / \mathrm{m} 2)$, and obese $([?] 30 \mathrm{~kg} / \mathrm{m} 2)^{12}$. In Slovenia, maternal weight is recorded at the first appointment in pregnancy and all appointments after. The mean gestational week at the first appointment in pregnancy was nine weeks. For the calculation of the GWG z-score, we used the same method as described before ${ }^{13}$. Preeclampsia was defined as the presence of hypertension (blood pressure [?] 140 and/or $90 \mathrm{mmHg}$ ) and any other end-organ dysfunction after the 20th week of gestation ${ }^{14}$. National guidelines for screening and diagnosing GDM changed during the study period. Until 2012, GDM was diagnosed in Slovenia using the two-step approach: screening with $50 \mathrm{~g}$ oral glucose load and, when indicated, performing a $100 \mathrm{~g}$ oral glucose tolerance test (OGTT) using the Carpenter and Coustan criteria ${ }^{15}$. Since 2012, we diagnose GDM using the one-step approach by a 75 -g OGTT according to the 2010 International Association of Diabetes and Pregnancy Study Groups Consensus ${ }^{16}$. SGA was a neonate with birthweight below the 10th percentile for gestational age and gender-based on a Slovenian Birth Weight Standards ${ }^{17}$. A nulliparous woman was defined as a pregnant woman who had no previous viable pregnancies.

\section{Statistics}

A descriptive analysis was performed using absolute and relative frequencies for categorical variables and mean value with standard deviation for continuous variables. Then, we performed Pearson's Chi-Square and t-test, as appropriate, of clinical and demographic characteristics of women between the groups. We used logistic regression to evaluate an association between the mode of conception and preterm delivery in infertile women after reproductive surgery. The logistic regression model was adjusted for variables which presented as significantly different between the spontaneous and IVF/ICSI group in descriptive analysis. The association was presented as adjusted odds ratio (aOR) with $95 \%$ confidence interval (95\% CI).

For the case-control study of the effect of reproductive surgery on preterm delivery, we used the propensity score (PS) method. Controls were selected from among all fertile women $(\mathrm{n}=100765)$ who delivered in the same period using PS matching. In the PS model, we included maternal age as a continuous variable, BMI as a categorical variable (underweight, normal weight, obese), and dichotomous variables: previous conization, 
chronic diseases (pre-pregnancy hypertension, pre-pregnancy diabetes, kidney, heart, thyroid and/or mental disease), previous preterm delivery, smoking, and multiple pregnancies. We performed 1:1 matching with an optimal matching algorithm with a calliper width of the linear predictor of 0.1 standard deviations. The balance between the control and treated group was considered well when the value of the standardized difference was $<0.1$. The effect of reproductive surgery on preterm delivery was evaluated in the PS-matched sample by Pearson's Chi-Square test and presented as the odds ratio (OR) with $95 \%$ confidential interval (95\% CI).

Considering an increase in preterm delivery rate by $30 \%$ in infertile women, within the limit of the number of treated women, the study's power was 0.78 at a $5 \%$ Type I error rate.

For statistical calculations, we used statistical program IBM SPSS Statistics v25 and $\mathrm{R}^{18}$ with R-package "Matchlt"19. For all calculations, a two-sided probability $(p)$ value $<0.05$ was considered statistically significant.

\section{Ethical approval}

The study of infertile women was approved by the National Medical Ethics Committee at the Ministry of Health of the Republic of Slovenia (No. 0120-174/2018/6) and was conducted following the WMA Declaration of Helsinki. The retrospective analysis of anonymous entries of fertile women from NPIS was exempt from approval by the ethical committee by the Slovenian law (Personal Data Protection Act; Article 17). The Slovenian National Institute of Public Health as the data controller and the Division of Obstetrics and Gynecology of the University Medical Centre Ljubljana as the data processor signed the contract on NPIS data transmission according to the Personal Data Protection Act, Article 11, every five years. The last contract was signed on 25th July 2019.

The authors received no funding.

\section{Results}

Among 761 infertile women with reproductive surgery, 428 (56.2\%) women conceived spontaneously, and 333 $(43.8 \%)$ conceived after IVF/ICSI. There were 58 pairs of twins $(7.23 \%)$. The incidence of twin pregnancies was lower after spontaneous conception than after IVF/ICSI (11 (2.6\%) vs. 47 (14.1\%); P-value <0.001).

The most common indication for fertility treatment was endometriosis $(228 ; 32.4 \%)$ with no significant difference between the spontaneous conception and IVF/ICSI group (Table S1).

Among 761 infertile women, 703 women had a singleton pregnancy. Compared with women who conceived spontaneously, women who conceived after IVF/ICSI were significantly older (33.08 \pm 3.13 vs. $31.81 \pm 2.24$; P-value $<0.001)$, more often older than 35 years ( $37.4 \%$ vs. $27.3 \%$, P-value 0.005$)$, and nulliparous (90.2\% vs. 81.5\%; P value 0.002) (Table S2). We found no significant differences between spontaneous and IVF/ICSI conception concerning the pre-gestational BMI, pre-gestational BMI $<18.5 \mathrm{~kg} / \mathrm{m} 2$, pre-gestational BMI [?] $30 \mathrm{~kg} / \mathrm{m} 2$, GWG z-score, GWG z-score $>+2$, or $>-2$, pre-gestational hypertension, pre-gestational diabetes, chronic kidney disease, other chronic diseases, conization, uterine anomalies, hysteroscopy (diagnostic/therapeutic), smoking during pregnancy, previous preterm delivery, preeclampsia/eclampsia, gestational diabetes and birth of an SGA neonate (Table S2). Univariate analysis showed that women who conceived after IVF/ICSI significantly more often delivered $<32$ gestational weeks (3.8\% vs. $1.4 \%$; P value 0.041$)$ (Table S2). However, logistic regression analysis adjusted for maternal age and nulliparity disclosed no significant association between the mode of conception and all preterm deliveries $<37$ gestational weeks, spontaneous preterm deliveries $<37$ weeks, as well as all preterm deliveries $<32$ gestational weeks (Table 1 ).

In the second part of the study, we evaluated the effect of reproductive surgery on preterm delivery as a treatment-related adverse outcome. Almost half of the women in the infertility group conceived after IVF/ICSI (43.8\%). Compared with fertile women before PS matching, infertile women were older at delivery, more often nulliparous, they more often suffer from chronic diseases, had uterine anomalies, and miscarriage previously, all of which may increase the risk of preterm delivery (Table 2). Also, among infertile women, 
there were more of those who had numerous co-existent risk factors for preterm delivery (Figure 1). After PS matching, the fertile and infertile women were well balanced for the chosen possible risk factors for preterm delivery, also concerning the number of co-existent risk factors per woman (Figure 1, Table 2). In the PS matched sample, the incidences of preterm delivery $<37$ and $<32$ gestational weeks were higher in the infertile women. However, the differences did not reach a statistical significance (Table 3).

Using PS matching, we also calculated the odds of preterm delivery in the group of infertile women who conceived spontaneously and after IVF/ICSI separately and found no significant differences compared with fertile women. Compared with fertile women, the odds of preterm delivery $<37$ weeks in infertile women who conceived spontaneously was 1.51 (95\% CI $0.93-2.43$; p-value 0.093$)$, and $<32$ weeks was $0.72(95 \% \mathrm{CI}$ 0.29-1.81; $p$-value 0.486). Compared with fertile women, the odds of preterm delivery $<37$ weeks in infertile women who conceived after IVF/ET was 1.29 (95\%CI 0.86-1.94;p-value 0.217), and < 32 weeks was 1.09 (95\% CI 0.48-2.52; p-value 0.832).

\section{Discussion}

\section{Main Findings}

In the present study, we found that, in infertile women with singleton pregnancies who underwent reproductive surgery before conception, the risk of preterm delivery was not associated with the mode of conception. Also, we found that reproductive surgery in infertile women had no significant treatment-related side effects in terms of preterm delivery neither $<37$ gestational weeks nor $<32$ gestational weeks.

\section{Strengths and Limitations}

The main limitation of our study is its retrospective observational design in the second part of the study, which does not account for all potential co-founders. Secondly, despite incorporated automatic checkpoints, the computerized database is also prone to human errors. Thirdly, infertile women were heterogenous regarding indication for reproductive surgery which might influence the insignificant difference in preterm delivery in regard to the mode of conception. The main strength of our study is a novel approach to exploring the effect of fertility treatment on preterm delivery as a treatment-related adverse outcome. Using PS matching approach allowed us to balance the treated and untreated group for some of the main co-founders and also for the number of co-existing possible risk factors for preterm delivery per woman making the observational study close to a randomized study. Therefore, the PS matching approach enables higher control over cofounding, reduces bias, and adds to higher prediction estimation ${ }^{20-21}$. However, the number of outcomes in our study was low, especially of preterm deliveries $<32$ weeks, which might influence the precision of estimation. For that reason, the result should be treated with caution.

\section{Interpretation}

Evidence shows that conception after IVF/ICSI increases the odds of preterm delivery when analysed in population-based cohorts ${ }^{4,5,22-24}$. Contrary to those findings, in our cohort of infertile women with singleton pregnancy after reproductive surgery, IVF/ICSI, compared to spontaneous conception, did not increase the odds of preterm delivery. Still, there are few reports on an outcome of spontaneous conception after reproductive surgery due to an opinion that reproductive surgery should only be performed as an initial part of infertility treatment before proceeding to IVF $/ \mathrm{ICSI}^{9}$. Nevertheless, encouraging reports on a high spontaneous pregnancy rate after reproductive surgery, as in this study, emerged in the last years ${ }^{8,10}$. Similar to our finding, Boyle et al. ${ }^{8}$ have found the low preterm delivery rate in women who conceived spontaneously after restorative reproductive medicine after failed IVF. Indeed, waiting for spontaneous conception in infertile women who are often at advanced reproductive age is discouraging. However, besides lower treatment burden for women and lower medical expenses, an essential advantage of a spontaneous conception after reproductive surgery is a lower rate of multiple pregnancies compared with IVF/ICSI, which was evident in our cohort. Precisely lowering the multiple pregnancy rate is the only preventive measure that we can take to reduce preterm delivery risk in women who need an infertility treatment ${ }^{25}$.

We report that reproductive surgery in infertile women had no significant effect on preterm delivery, re- 
gardless of the mode of conception. However, Valenzuela-Alcaraz et al. ${ }^{26}$ have found the significantly higher prevalence of overall pregnancy complications in all studied infertility groups regardless of the infertility treatment, preterm delivery being the highest in the IVF/ICSI group. Also, Dunietz et al. ${ }^{6}$, when compared spontaneous conception with assisted reproductive techniques (ART) conception in women with singleton pregnancy after infertility treatment, have reported an increased preterm delivery risk after ART within each of the treatment group. However, compared with women who had trouble conceiving but conceived without any assistance, Oberg et al. ${ }^{27}$ had reported that when women received some fertility treatment, the odds of preterm delivery were higher through independent multiple gestations. All mentioned studies have evaluated a relative relationship between infertility treatment and preterm delivery using multivariate regression models, which have well-documented limitations as a means to explore causal relationships ${ }^{28}$. In our study, using the propensity score method, fertile women and women who received infertility treatment were well balanced not only for every single risk factor for preterm delivery but also for the number of co-existing risk factors per woman. Considering this, our finding that reproductive surgery had no significant effect on preterm delivery in the well-balanced sample suggests that the higher rate of women with co-existing risk factors in infertile women may be the main contributor to an increased risk of preterm delivery when compared with all fertile women.

In our study, the main indication for infertility treatment was endometriosis, in one-third of the women, which might contribute to our insignificant treatment-related side effect. Namely, Stern et al. have reported that among all ART deliveries, following singleton or multiple pregnancies, the increased preterm delivery risk was associated with male factor, ovulation disorders, tubal inflammation, but not with endometriosis ${ }^{7}$.

Our findings do not contradict other findings that, compared with all fertile women, preterm deliveries are higher in women who conceived after IVF/ICSI or received any infertility treatment ${ }^{29}$. What our study pointed out is that not the mode of conception or reproductive surgery, but rather maternal risk factors for preterm delivery like high maternal age, nulliparity, and chronic diseases, which were more prevalent in women who received infertility treatment and even more prevalent in women who conceived after IVF/ICSI might contribute to the higher prevalence of preterm delivery when compared to all fertile women. Besides, to our finding, the higher prevalence of co-existing risk factors for preterm delivery per woman may be the most critical contributor to the higher rate of preterm delivery in women who received infertility treatment.

\section{Conclusion}

Our study highlighted that in infertile women with singleton pregnancies after reproductive surgery, the preterm delivery rate is comparable between spontaneous conception and conception after IVF/ICSI. The preterm delivery risk seems to be associated, preferably, with maternal risk factors and their co-existence rather than with the mode of conception as well as reproductive surgery. Thus, reproductive surgery has a valuable role in infertility treatment that enables a high ratio of spontaneous conceptions and should not be avoided before proceeding to IVF/ICSI. In selected infertile women with no obvious indication for IVF/ICSI or advanced age, we should encourage spontaneous conception after reproductive surgery. So, we can spare women of a psychosocial and medical treatment burden associated with IVF/ICSI procedure as well as decrease the risk of multiple pregnancies.

\section{Disclosure of interest}

The authors report no conflict of interest.

\section{Contribution to authorship}

TPS designed the study, reviewed the literature and wrote the manuscript. HBF contributed the data, designed the study, reviewed the literature and critically revised the manuscript. EBV and SK contributed the data and critically revised the manuscript. IV and TB analyzed the data and critically revised the manuscript.

\section{Details of ethics approval}


The study of infertile women was approved by the National Medical Ethics Committee at the Ministry of Health of the Republic of Slovenia (No. 0120-174/2018/6) and was conducted following the WMA Declaration of Helsinki. The retrospective analysis of anonymous entries of fertile women from NPIS was exempt from approval by the ethical committee by the Slovenian law (Personal Data Protection Act; Article 17). The Slovenian National Institute of Public Health as the data controller and the Division of Obstetrics and Gynecology of the University Medical Centre Ljubljana as the data processor signed the contract on NPIS data transmission according to the Personal Data Protection Act, Article 11, every five years. The last contract was signed on 25th July 2019.

\section{Funding}

We received no financial support and used no services from commercial organizations. The authors entirely did the study within the Division of Obstetrics and Gynecology, University Medical Centre Ljubljana.

\section{References}

1. Saigal S, Doyle LW. An overview of mortality and sequelae of preterm birth from infancy to adulthood. Lancet. 2008;371(9608):261-9.

2. Heino A, Gissler M, Hindori-Mohangoo AD, Blondel B, Klungsoyr K, Verdenik I, et al. Variations in multiple birth rates and impact on perinatal outcomes in Europe. PLoS One. 2016;11(3):1-15.

3. El-Toukhy T, Bhattacharya S AV on behalf of the RC of O and G. Multiple Pregnancies Following Assisted Conception: Scientific Impact Paper No. 22. BJOG An Int J Obstet Gynaecol. 2018;125(5):e128.

4. Jančar N, Mihevc Ponikvar B, Tomšič S, Vrtačnik Bokal E, Korošec S. Is IVF/ISCI an Independent Risk Factor for Spontaneous Preterm Birth in Singletons? A Population-Based Cohort Study. Biomed Res Int. 2018;2018.

5. Dagklis T, Tsakiridis I, Mamopoulos A, Dardavessis T, Athanasiadis A. Modifiable risk factors for spontaneous preterm birth in nulliparous women: a prospective study. J Perinat Med. 2020 Feb 25;48(2):96-101.

6. Dunietz GL, Holzman C, Zhang Y, Li C, Todem D, Boulet SL, et al. Assisted reproduction and risk of preterm birth in singletons by infertility diagnoses and treatment modalities: a population-based study. J Assist Reprod Genet. 2017;34(11):1529-35.

7. Stern J, Luke B, Tobias M, Gopal D, Hornstein M, Diop H. Adverse Pregnancy and birth outcomes associated with underlying diagnosis with and without ART therapy. Fertil Steril. 2015;103(6):143845.

8. Boyle PC, de Groot T, Andralojc KM, Parnell TA. Healthy singleton pregnancies from Restorative Reproductive Medicine (RRM) after failed IVF. Front Med. 2018;5:1-7.

9. Bosteels J, Van Herendael B, Weyers S, D'Hooghe T. The position of diagnostic laparoscopy in current fertility practice. Hum Reprod Update. 2007;13(5):477-85.

10. Ban Frangez H, Korošec S, Pozlep B, Jancar N, Salamun V, Vogler A, et al. Spontaneous pregnancy rates after reproductive surgery. Reprod Biomed Online. 2017;35(2):165-73.

11. Clinical Standards Committee. ISUOG practice guidelines: Performance of first-trimester fetal ultrasound scan. Ultrasound Obstet Gynecol. 2013;41(1):102-13.

12. Khanolkar AR, Hanley GE, Koupil I, Janssen PA. 2009 IOM guidelines for gestational weight gain: how well do they predict outcomes across ethnic groups? Ethn Heal. 2017;0(0):1-16.

13. Premru-Srsen T, Kocic Z, Fabjan Vodusek V, Geršak K, Verdenik I. Total gestational weight gain and the risk of preeclampsia by pre-pregnancy body mass index categories: a population-based cohort study from 2013 to 2017. J Perinat Med. 2019 Aug 27;47(6):585-591.

14. Brown MA, Magee LA, Kenny LC, Karumanchi SA, McCarthy FP, Saito S, et al. The hypertensive disorders of pregnancy: ISSHP classification, diagnosis \& management recommendations for international practice. Pregnancy Hypertens. 2018;13:291-310.

15. Hod M, Kapur A, Sacks DA, Hadar E, Agarwal M, Di Renzo GC, et al. The International Federation of Gynecology and Obstetrics (FIGO) Initiative on gestational diabetes mellitus: A pragmatic guide 
for diagnosis, management, and care. Int J Gynaecol Obstet. 2015 Oct;131 Suppl 3:S173-211.

16. Carpenter MW, Coustan DR. Criteria for screening tests for gestational diabetes. Am J Obstet Gynecol. 1982 Dec 1;144(7):768-73.

17. Verdenik I. Standards for birthweight, body length and head circumpherence for gestational age at birth for Slovenian neonates born 1987-96. Zdr Vestn. 2000;69:153-156.

18. Core Team (2019). R: A language and environment for statistical computing. R Foundation for Statistical Computing, Vienna, Austria. URL https://www.R-project.org/

19. Daniel E. Ho, Kosuke Imai, Gary King, Elizabeth A. Stuart (2011). MatchIt: Nonparametric Preprocessing for Parametric Causal Inference. J Stat Softw. 2011;42(8):1-28.

20. Rosenbaum P, Rubin D. The Central Role of the Propensity Score in Observational Studies for Causal Effects. Biometrika. 1983;70(1):41-55.

21. Cepeda MS, Boston R, Farrar JT, Strom BL. Comparison of logistic regression versus propensity score when the number of events is low and there are multiple confounders. Am J Epidemiol. 2003;158(3):280-7.

22. Cavoretto P, Candiani M, Giorgione V, Inversetti A, Abu-Saba MM, Tiberio F, et al. Risk of spontaneous preterm birth in singleton pregnancies conceived after IVF/ICSI treatment: meta-analysis of cohort studies. Ultrasound Obstet Gynecol. 2018;51(1):43-53.

23. Ballesta-Castillejos A, Gomez-Salgado J, Rodriguez-Almagro J, Ortiz-Esquinas I, Hernández-Martínez A. Obstetric and perinatal complications associated with assisted reproductive treatment in Spain. J Assist Reprod Genet. 2019;36(12):2435-2445.

24. Declercq E, Luke B, Belanoff C, Cabral H, Diop H, Gopal D, et al. Perinatal outcomes associated with assisted reproductive technology: The Massachusetts Outcomes Study of Assisted Reproductive Technologies (MOSART). Fertil Steril. 2015;103(4):888-95.

25. Luke B. Pregnancy and birth outcomes in couples with infertility with and without assisted reproductive technology: with an emphasis on US population-based studies. Am J Obstet Gynecol. 2017;217(3):27081.

26. Valenzuela-Alcaraz B, Crispi F, Manau D, Cruz-Lemini M, Borras A, Balasch J, et al. Differential effect of mode of conception and infertility treatment on fetal growth and prematurity. J Matern Neonatal Med. 2016;29(23):3879-84.

27. Oberg AS, Vander Weele TJ, Almqvist C, Hernandez-Diaz S. Pregnancy complications following fertility treatment-disentangling the role of multiple gestation. Int J Epidemiol. 2018;47(4):1333-42.

28. Kaufman JS, MacLehose RF, Kaufman S. A further critique of the analytic strategy of adjusting for covariates to identify biologic mediation. Epidemiol Perspect Innov. 2004;1.

29. Qin JB, Sheng XQ, Wu D, Gao SY, You YP, Yang TB, et al. Worldwide prevalence of adverse pregnancy outcomes among singleton pregnancies after in vitro fertilization/intracytoplasmic sperm injection: a systematic review and meta-analysis. Arch Gynecol Obstet. 2017;295(2):285-301.

Figure 1. Percentage of women with co-existing risk factors for preterm delivery per woman before (A) and after (B) propensity score matching. 


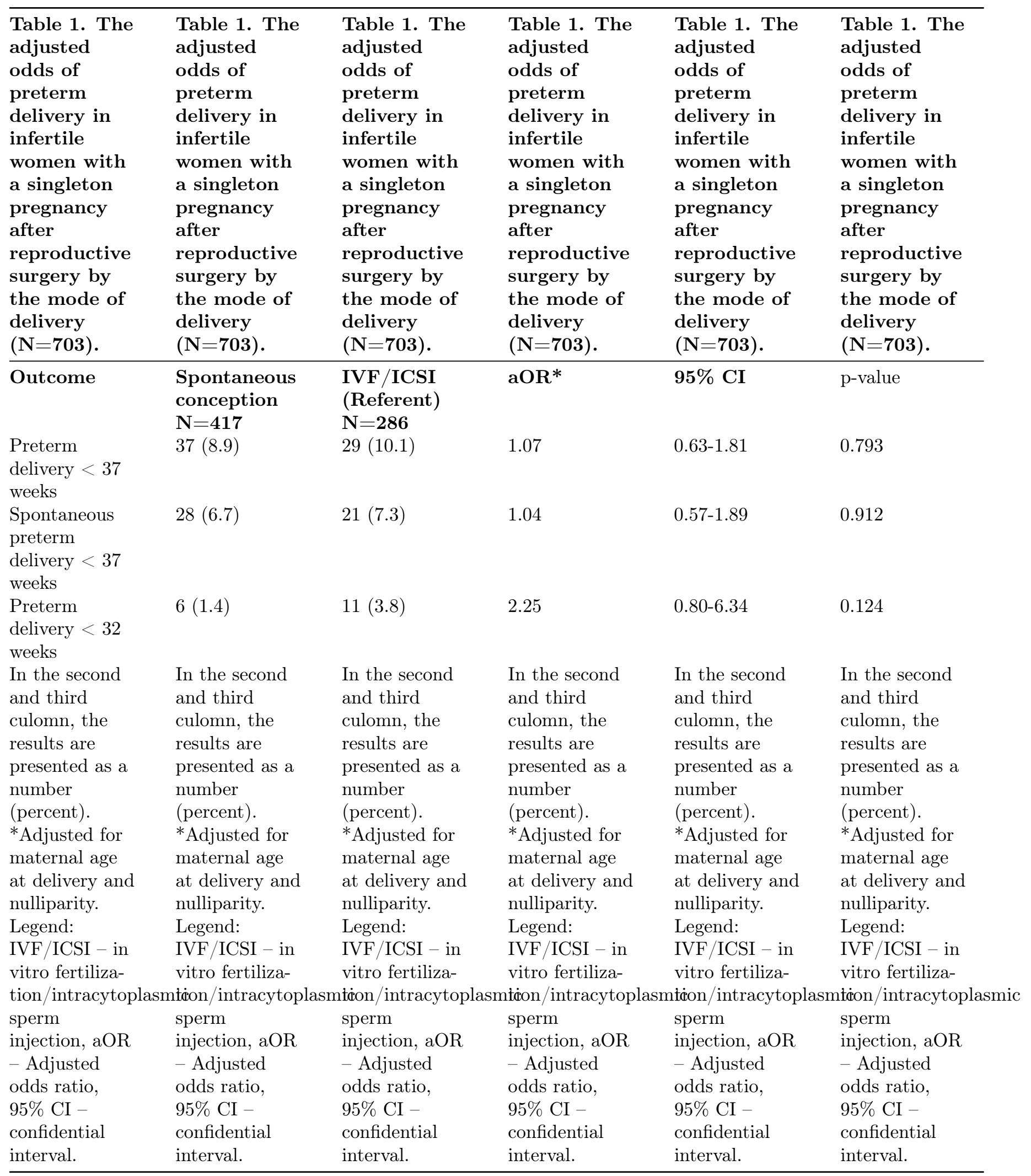




\begin{tabular}{|c|c|c|c|c|c|c|}
\hline $\begin{array}{l}\text { Table } 2 . \\
\text { Character- } \\
\text { istics of } \\
\text { fertile } \\
\text { (controls) } \\
\text { and } \\
\text { infertile } \\
\text { women } \\
\text { after re- } \\
\text { productive } \\
\text { surgery } \\
\text { before and } \\
\text { after PS } \\
\text { matching. }\end{array}$ & $\begin{array}{l}\text { Table } 2 . \\
\text { Character- } \\
\text { istics of } \\
\text { fertile } \\
\text { (controls) } \\
\text { and } \\
\text { infertile } \\
\text { women } \\
\text { after re- } \\
\text { productive } \\
\text { surgery } \\
\text { before and } \\
\text { after PS } \\
\text { matching. }\end{array}$ & $\begin{array}{l}\text { Table } 2 . \\
\text { Character- } \\
\text { istics of } \\
\text { fertile } \\
\text { (controls) } \\
\text { and } \\
\text { infertile } \\
\text { women } \\
\text { after re- } \\
\text { productive } \\
\text { surgery } \\
\text { before and } \\
\text { after PS } \\
\text { matching. }\end{array}$ & $\begin{array}{l}\text { Table } 2 . \\
\text { Character- } \\
\text { istics of } \\
\text { fertile } \\
\text { (controls) } \\
\text { and } \\
\text { infertile } \\
\text { women } \\
\text { after re- } \\
\text { productive } \\
\text { surgery } \\
\text { before and } \\
\text { after PS } \\
\text { matching. }\end{array}$ & $\begin{array}{l}\text { Table } 2 . \\
\text { Character- } \\
\text { istics of } \\
\text { fertile } \\
\text { (controls) } \\
\text { and } \\
\text { infertile } \\
\text { women } \\
\text { after re- } \\
\text { productive } \\
\text { surgery } \\
\text { before and } \\
\text { after PS } \\
\text { matching. }\end{array}$ & $\begin{array}{l}\text { Table } 2 . \\
\text { Character- } \\
\text { istics of } \\
\text { fertile } \\
\text { (controls) } \\
\text { and } \\
\text { infertile } \\
\text { women } \\
\text { after re- } \\
\text { productive } \\
\text { surgery } \\
\text { before and } \\
\text { after PS } \\
\text { matching. }\end{array}$ & $\begin{array}{l}\text { Table } 2 . \\
\text { Character- } \\
\text { istics of } \\
\text { fertile } \\
\text { (controls) } \\
\text { and } \\
\text { infertile } \\
\text { women } \\
\text { after re- } \\
\text { productive } \\
\text { surgery } \\
\text { before and } \\
\text { after PS } \\
\text { matching. }\end{array}$ \\
\hline \multirow[t]{2}{*}{ Variable } & $\begin{array}{l}\text { All women } \\
(n=100 \\
765)\end{array}$ & $\begin{array}{l}\text { All women } \\
(n=100 \\
765)\end{array}$ & $\begin{array}{l}\text { All women } \\
(n=100 \\
765)\end{array}$ & $\begin{array}{l}\text { PS } \\
\text { matched } \\
\text { sample } \\
(n=1516)\end{array}$ & $\begin{array}{l}\text { PS } \\
\text { matched } \\
\text { sample } \\
(n=1516)\end{array}$ & $\begin{array}{l}\text { PS } \\
\text { matched } \\
\text { sample } \\
(n=1516)\end{array}$ \\
\hline & $\begin{array}{l}\text { Fertile } \\
\text { women } \\
\mathrm{n}=100007\end{array}$ & $\begin{array}{l}\text { Infertile } \\
\text { women } \\
\mathrm{n}=758^{*}\end{array}$ & Std. Diff. & $\begin{array}{l}\text { Fertile } \\
\text { women } \\
\mathrm{n}=758\end{array}$ & $\begin{array}{l}\text { Infertile } \\
\text { women } \\
\mathrm{n}=758\end{array}$ & Std. Diff. \\
\hline $\begin{array}{l}\text { Maternal } \\
\text { age at } \\
\text { delivery } \\
\text { (years) } \\
\text { BMI } \\
\left(\mathrm{kg} / \mathrm{m}^{2}\right)\end{array}$ & $30.2 \pm 4.8$ & $32.4 \pm 4.2$ & 0.537 & & $32.4 \pm 4.2$ & -0.017 \\
\hline $\mathrm{BMI}<18.5$ & $4712(4.7)$ & $44(5.8)$ & 0.047 & $45(5.9)$ & $44(5.8)$ & -0.006 \\
\hline $\begin{array}{l}\text { BMI } \\
18.5-24.99\end{array}$ & $66205(66.3)$ & $501(66.1)$ & -0.004 & $504(66.5)$ & $501(66.1)$ & -0.008 \\
\hline $\begin{array}{l}\text { BMI } 25- \\
29.99\end{array}$ & $19169(19.2)$ & $131(17.3)$ & -0.050 & $129(17.0)$ & $131(17.3)$ & 0.007 \\
\hline $\mathrm{BMI}>30$ & $9810(9.8)$ & $82(10.8)$ & 0.032 & $80(10.6)$ & $82(10.8)$ & 0.009 \\
\hline Nulliparous & $\begin{array}{l}48312 \\
(48.3)\end{array}$ & $646(85.2)$ & 1.040 & $644(85.0)$ & $646(85.2)$ & 0.007 \\
\hline Smoking & $9486(9.5)$ & $57(7.5)$ & -0.074 & $50(6.6)$ & $57(7.5)$ & 0.035 \\
\hline $\begin{array}{l}\text { Chronic } \\
\text { diseases }\end{array}$ & $\begin{array}{l}10953 \\
(11.0)\end{array}$ & 135 (17.8) & 0.179 & $131(17.3)$ & $135(17.8)$ & 0.014 \\
\hline $\begin{array}{l}\text { Previous } \\
\text { miscarriage }\end{array}$ & $\begin{array}{l}18155 \\
(18.2)\end{array}$ & $184(24.3)$ & 0.142 & $181(23.9)$ & $184(24.3)$ & 0.009 \\
\hline $\begin{array}{l}\text { Previous } \\
\text { conization }\end{array}$ & $3752(3.8)$ & $33(4.4)$ & 0.029 & $28(3.7)$ & $33(4.4)$ & 0.032 \\
\hline $\begin{array}{l}\text { Uterine } \\
\text { anomaly }\end{array}$ & $4668(4.7)$ & $348(45.9)$ & 0.827 & 347 (45.8) & $348(45.9)$ & 0.003 \\
\hline $\begin{array}{l}\text { Previous } \\
\text { preterm } \\
\text { delivery }\end{array}$ & 3081 (3.1) & $13(1.7)$ & -0.105 & $16(2.1)$ & $13(1.7)$ & -0.031 \\
\hline $\begin{array}{l}\text { Multiple } \\
\text { pregnancy }\end{array}$ & $1773(1.8)$ & $58(7.7)$ & 0.221 & $56(7.4)$ & $58(7.7)$ & 0.010 \\
\hline
\end{tabular}




\begin{tabular}{|c|c|c|c|c|c|c|}
\hline $\begin{array}{l}\text { Table } 2 . \\
\text { Character- } \\
\text { istics of } \\
\text { fertile } \\
\text { (controls) } \\
\text { and } \\
\text { infertile } \\
\text { women } \\
\text { after re- } \\
\text { productive } \\
\text { surgery } \\
\text { before and } \\
\text { after PS } \\
\text { matching. }\end{array}$ & $\begin{array}{l}\text { Table } 2 . \\
\text { Character- } \\
\text { istics of } \\
\text { fertile } \\
\text { (controls) } \\
\text { and } \\
\text { infertile } \\
\text { women } \\
\text { after re- } \\
\text { productive } \\
\text { surgery } \\
\text { before and } \\
\text { after PS } \\
\text { matching. }\end{array}$ & $\begin{array}{l}\text { Table } 2 . \\
\text { Character- } \\
\text { istics of } \\
\text { fertile } \\
\text { (controls) } \\
\text { and } \\
\text { infertile } \\
\text { women } \\
\text { after re- } \\
\text { productive } \\
\text { surgery } \\
\text { before and } \\
\text { after PS } \\
\text { matching. }\end{array}$ & $\begin{array}{l}\text { Table } 2 . \\
\text { Character- } \\
\text { istics of } \\
\text { fertile } \\
\text { (controls) } \\
\text { and } \\
\text { infertile } \\
\text { women } \\
\text { after re- } \\
\text { productive } \\
\text { surgery } \\
\text { before and } \\
\text { after PS } \\
\text { matching. }\end{array}$ & $\begin{array}{l}\text { Table } 2 . \\
\text { Character- } \\
\text { istics of } \\
\text { fertile } \\
\text { (controls) } \\
\text { and } \\
\text { infertile } \\
\text { women } \\
\text { after re- } \\
\text { productive } \\
\text { surgery } \\
\text { before and } \\
\text { after PS } \\
\text { matching. }\end{array}$ & $\begin{array}{l}\text { Table } 2 . \\
\text { Character- } \\
\text { istics of } \\
\text { fertile } \\
\text { (controls) } \\
\text { and } \\
\text { infertile } \\
\text { women } \\
\text { after re- } \\
\text { productive } \\
\text { surgery } \\
\text { before and } \\
\text { after PS } \\
\text { matching. }\end{array}$ & $\begin{array}{l}\text { Table } 2 . \\
\text { Character- } \\
\text { istics of } \\
\text { fertile } \\
\text { (controls) } \\
\text { and } \\
\text { infertile } \\
\text { women } \\
\text { after re- } \\
\text { productive } \\
\text { surgery } \\
\text { before and } \\
\text { after PS } \\
\text { matching. }\end{array}$ \\
\hline $\begin{array}{l}\text { Results are } \\
\text { presented as } \\
\text { a mean } \pm \\
\text { SD or No. } \\
\text { (\%) as } \\
\text { appropriate. } \\
\text { *3 women } \\
\text { droped out } \\
\text { from } \\
\text { propensity } \\
\text { score } \\
\text { calculation } \\
\text { due to lack } \\
\text { of all } \\
\text { variables. } \\
\text { Legend: } \\
\text { BMI - body } \\
\text { mass index }\end{array}$ & $\begin{array}{l}\text { Results are } \\
\text { presented as } \\
\text { a mean } \pm \\
\text { SD or No. } \\
(\%) \text { as } \\
\text { appropriate. } \\
\text { *3 women } \\
\text { droped out } \\
\text { from } \\
\text { propensity } \\
\text { score } \\
\text { calculation } \\
\text { due to lack } \\
\text { of all } \\
\text { variables. } \\
\text { Legend: } \\
\text { BMI - body } \\
\text { mass index }\end{array}$ & $\begin{array}{l}\text { Results are } \\
\text { presented as } \\
\text { a mean } \pm \\
\text { SD or No. } \\
(\%) \text { as } \\
\text { appropriate. } \\
\text { *3 women } \\
\text { droped out } \\
\text { from } \\
\text { propensity } \\
\text { score } \\
\text { calculation } \\
\text { due to lack } \\
\text { of all } \\
\text { variables. } \\
\text { Legend: } \\
\text { BMI - body } \\
\text { mass index }\end{array}$ & $\begin{array}{l}\text { Results are } \\
\text { presented as } \\
\text { a mean } \pm \\
\text { SD or No. } \\
\text { (\%) as } \\
\text { appropriate. } \\
\text { *3 women } \\
\text { droped out } \\
\text { from } \\
\text { propensity } \\
\text { score } \\
\text { calculation } \\
\text { due to lack } \\
\text { of all } \\
\text { variables. } \\
\text { Legend: } \\
\text { BMI - body } \\
\text { mass index }\end{array}$ & $\begin{array}{l}\text { Results are } \\
\text { presented as } \\
\text { a mean } \pm \\
\text { SD or No. } \\
\text { (\%) as } \\
\text { appropriate. } \\
\text { *3 women } \\
\text { droped out } \\
\text { from } \\
\text { propensity } \\
\text { score } \\
\text { calculation } \\
\text { due to lack } \\
\text { of all } \\
\text { variables. } \\
\text { Legend: } \\
\text { BMI - body } \\
\text { mass index }\end{array}$ & $\begin{array}{l}\text { Results are } \\
\text { presented as } \\
\text { a mean } \pm \\
\text { SD or No. } \\
\text { (\%) as } \\
\text { appropriate. } \\
\text { *3 women } \\
\text { droped out } \\
\text { from } \\
\text { propensity } \\
\text { score } \\
\text { calculation } \\
\text { due to lack } \\
\text { of all } \\
\text { variables. } \\
\text { Legend: } \\
\text { BMI - body } \\
\text { mass index }\end{array}$ & $\begin{array}{l}\text { Results are } \\
\text { presented as } \\
\text { a mean } \pm \\
\text { SD or No. } \\
(\%) \text { as } \\
\text { appropriate. } \\
\text { *3 women } \\
\text { droped out } \\
\text { from } \\
\text { propensity } \\
\text { score } \\
\text { calculation } \\
\text { due to lack } \\
\text { of all } \\
\text { variables. } \\
\text { Legend: } \\
\text { BMI - body } \\
\text { mass index }\end{array}$ \\
\hline
\end{tabular}

\begin{tabular}{|c|c|c|c|c|c|}
\hline $\begin{array}{l}\text { Table 3. The } \\
\text { effect of } \\
\text { reproductive } \\
\text { surgery on } \\
\text { preterm } \\
\text { delivery in } \\
\text { the } \\
\text { PS-matched } \\
\text { sample. }\end{array}$ & $\begin{array}{l}\text { Table 3. The } \\
\text { effect of } \\
\text { reproductive } \\
\text { surgery on } \\
\text { preterm } \\
\text { delivery in } \\
\text { the } \\
\text { PS-matched } \\
\text { sample. }\end{array}$ & $\begin{array}{l}\text { Table 3. The } \\
\text { effect of } \\
\text { reproductive } \\
\text { surgery on } \\
\text { preterm } \\
\text { delivery in } \\
\text { the } \\
\text { PS-matched } \\
\text { sample. }\end{array}$ & $\begin{array}{l}\text { Table 3. The } \\
\text { effect of } \\
\text { reproductive } \\
\text { surgery on } \\
\text { preterm } \\
\text { delivery in } \\
\text { the } \\
\text { PS-matched } \\
\text { sample. }\end{array}$ & $\begin{array}{l}\text { Table 3. The } \\
\text { effect of } \\
\text { reproductive } \\
\text { surgery on } \\
\text { preterm } \\
\text { delivery in } \\
\text { the } \\
\text { PS-matched } \\
\text { sample. }\end{array}$ & $\begin{array}{l}\text { Table 3. The } \\
\text { effect of } \\
\text { reproductive } \\
\text { surgery on } \\
\text { preterm } \\
\text { delivery in } \\
\text { the } \\
\text { PS-matched } \\
\text { sample. }\end{array}$ \\
\hline Outcome & Fertile women & $\begin{array}{l}\text { Infertile } \\
\text { women } \\
\text { (Referent) } \\
\mathbf{N}=758\end{array}$ & OR & $95 \% \mathrm{CI}$ & p-value \\
\hline $\begin{array}{l}\text { Preterm } \\
\text { delivery }<37 \\
\text { weeks }\end{array}$ & $85(11.2)$ & $108(14.2)$ & 1.31 & $0.97-1.78$ & 0.076 \\
\hline
\end{tabular}




\begin{tabular}{|c|c|c|c|c|c|}
\hline $\begin{array}{l}\text { Table } 3 . \text { The } \\
\text { effect of } \\
\text { reproductive } \\
\text { surgery on } \\
\text { preterm } \\
\text { delivery in } \\
\text { the } \\
\text { PS-matched } \\
\text { sample. }\end{array}$ & $\begin{array}{l}\text { Table } 3 \text {. The } \\
\text { effect of } \\
\text { reproductive } \\
\text { surgery on } \\
\text { preterm } \\
\text { delivery in } \\
\text { the } \\
\text { PS-matched } \\
\text { sample. }\end{array}$ & $\begin{array}{l}\text { Table } 3 . \text { The } \\
\text { effect of } \\
\text { reproductive } \\
\text { surgery on } \\
\text { preterm } \\
\text { delivery in } \\
\text { the } \\
\text { PS-matched } \\
\text { sample. }\end{array}$ & $\begin{array}{l}\text { Table 3. The } \\
\text { effect of } \\
\text { reproductive } \\
\text { surgery on } \\
\text { preterm } \\
\text { delivery in } \\
\text { the } \\
\text { PS-matched } \\
\text { sample. }\end{array}$ & $\begin{array}{l}\text { Table } 3 \text {. The } \\
\text { effect of } \\
\text { reproductive } \\
\text { surgery on } \\
\text { preterm } \\
\text { delivery in } \\
\text { the } \\
\text { PS-matched } \\
\text { sample. }\end{array}$ & $\begin{array}{l}\text { Table 3. The } \\
\text { effect of } \\
\text { reproductive } \\
\text { surgery on } \\
\text { preterm } \\
\text { delivery in } \\
\text { the } \\
\text { PS-matched } \\
\text { sample. }\end{array}$ \\
\hline $\begin{array}{l}\text { Preterm } \\
\text { delivery }<32 \\
\text { weeks }\end{array}$ & $13(1.7)$ & $20(2.6)$ & 1.57 & $0.78-3.18$ & 0.218 \\
\hline $\begin{array}{l}\text { In the second } \\
\text { nad third } \\
\text { culomn, the } \\
\text { results are } \\
\text { presented as a } \\
\text { number } \\
\text { (percent). } \\
\text { Legend: OR - } \\
\text { Odds ratio, } \\
\text { 95\% CI - } \\
\text { confidential } \\
\text { interval. }\end{array}$ & $\begin{array}{l}\text { In the second } \\
\text { nad third } \\
\text { culomn, the } \\
\text { results are } \\
\text { presented as a } \\
\text { number } \\
\text { (percent). } \\
\text { Legend: OR - } \\
\text { Odds ratio, } \\
95 \% \text { CI - } \\
\text { confidential } \\
\text { interval. }\end{array}$ & $\begin{array}{l}\text { In the second } \\
\text { nad third } \\
\text { culomn, the } \\
\text { results are } \\
\text { presented as a } \\
\text { number } \\
\text { (percent). } \\
\text { Legend: OR - } \\
\text { Odds ratio, } \\
\text { 95\% CI - } \\
\text { confidential } \\
\text { interval. }\end{array}$ & $\begin{array}{l}\text { In the second } \\
\text { nad third } \\
\text { culomn, the } \\
\text { results are } \\
\text { presented as a } \\
\text { number } \\
\text { (percent). } \\
\text { Legend: OR - } \\
\text { Odds ratio, } \\
\text { 95\% CI - } \\
\text { confidential } \\
\text { interval. }\end{array}$ & $\begin{array}{l}\text { In the second } \\
\text { nad third } \\
\text { culomn, the } \\
\text { results are } \\
\text { presented as a } \\
\text { number } \\
\text { (percent). } \\
\text { Legend: OR - } \\
\text { Odds ratio, } \\
\text { 95\% CI - } \\
\text { confidential } \\
\text { interval. }\end{array}$ & $\begin{array}{l}\text { In the second } \\
\text { nad third } \\
\text { culomn, the } \\
\text { results are } \\
\text { presented as a } \\
\text { number } \\
\text { (percent). } \\
\text { Legend: OR - } \\
\text { Odds ratio, } \\
95 \% \text { CI - } \\
\text { confidential } \\
\text { interval. }\end{array}$ \\
\hline
\end{tabular}

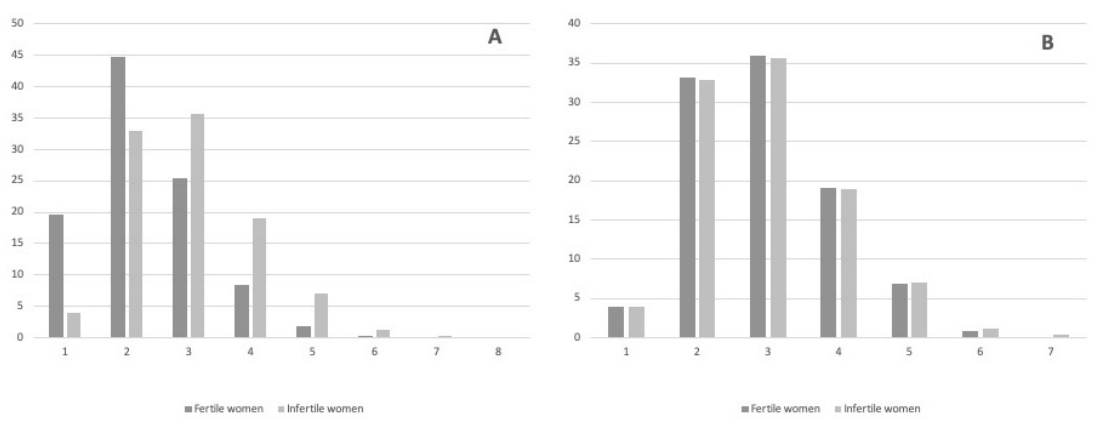

